\title{
LEGAL REGULATION OF THE LIMITED LIABILITY COMPANY IN NORTH MACEDONIA, ALBANIA, AND KOSOVO
}

\author{
Bashkim NUREDINI \\ Lecturer at the Faculty of Law, \\ University for Business and Technology, Pristina, Republic of Kosovo \\ E-mail: bashkim.nuredini@ubt-uni.net
}

\begin{abstract}
Ruzhdi MATOSHI
Assistant professor at the University for Business and Technology

Pristina, Republic of Kosovo

E-mail: ruzhdi.matoshi@ubt-uni.net
\end{abstract}

\begin{abstract}
This paper makes a comparative analysis of the normative regulation of the Limited Liability Companies (LLC) in North Macedonia, Albania, and Kosovo as the most popular form of business organization in continental Europe and beyond. According to the doctrinal analysis, the spread of this type of companies is due to its hybrid nature, i.e. the presence of the positive elements of personal and capital features. Namely, the idea behind is determined by the need to create a kind of "more flexible" space for individuals in a Joint Stock Company (JSC), but also to have more formal and less personal risk than in a public company. In the comparative law of companies, there are significant differences in terms of regulating the position of LLCs, so that in some countries the features typical of personal companies are more evident, while in other countries, the Joint Stock Companies as a personification of capital companies. Unlike a Joint Stock Company that engages large amount of capital, a LLC is featured by a smaller concentration of capital.
\end{abstract}

Keywords: Business, organization, limited, major deposit, basic capital, shareholders, management. 


\section{Introduction}

When it comes to selecting the most optimal form of organization of business activity, the practics shows that LLC is the most popular form in the countries of continental Europe and beyond. The prevalence of this form of company on a global scale is primarily attributed to its legal nature as a hybrid form of company. In a LLC, the legal attributes of personal companies are combined, as the representative of the public trade company, and the attributes of capital companies, where their representative is the joint stock company.

In the global legal landscape of a LLC, there is a different approach. Namely, some countries such as: Belgium, Romania, Hungary, Portugal, UK, etc., have incorporated the legal regulation of the Limited Liability Company in their company laws. The UK through amendments to Companies Act in 2006 which significantly reformed the rules of share capital of Private Company Limited by Shares (Ltd.) Namely, Article 542 of the Companies Act provides for the amount of the share capital of one pound, i.e. basically does not provide minimum amount of share capital, but as a rule in Article 542 entitled "Nominal value of shares". "Nominal value of shares" is provided that the share has a nominal amount of whole (fixed) number. On June 26, 2008, the German Parliament passed a law on major reform of the Limited Liability Company (Gesetz zur Modernisierung des GmbH Rechts und zur Bekämpfung von Missbräuchen), which introduced a simplified Limited Liability Company, better known as mini-doo haftungsbeschränkt (UG) or abbreviated UG. For this form of company provides minimum legal amount of 1 euro of principal (Mock, 2021). There are a small number of countries in which the matter of the Limited Liability Company is regulated in their commercial codes (Poland, Czech Republic, Slovakia, Bulgaria). Germany, Austria, Spain, Greece, Russia belong to the group of countries that regulate the matter by special laws. In Switzerland, a Limited Liability Company is governed by the 1911 Law of Obligations, as amended in 1936. The Republic of North Macedonia, Albania, and Kosovo belong to the group of countries that regulate the matter of Limited Liability Companiesin their company laws.

Being former communist countries, the establishment of LLCs in Albania, Kosovo, and North Macedonia began since the early 1990s, both from privatization of state and social ownership as well as newly established private enterprises. They actually became the most popular form of business organization to the present day. In order to understand why, we first need to review its legal term. What we know today as the LLC, has the origin from the Anglo-Saxon law as the "company with limited liability". The English name "private company" with the designation "Ltd" (limited) is considered the most suitable for making the company with limited liability. In Albanian as well as Kosovo law it is named Shoqëria me përgjegjësi të kufizuar ("Sh.P.K”), while in North Macedonia as Друштво со ограничена одговорност (“ДОО”). From a normative point of view, LTCNM (Law on Trade Companies of 
Northern Macedonia) along with the Laws on Trade Companies of Albania and Kosovo, belong to the scope of legislation that defines the LLC. ${ }^{1}$

According to paragraph 1 of Article 166 of the LTCNM, a LLC is a trade company in which one or more natural and legal persons participate with one investment in the pre-agreed share capital of the company where, the members/partners are not responsible for the obligations of the company. As we mentioned, the Albanian Company Law is part of the legislation that conceptually defines a LLC. This is done under the provisions of Article 68 of the Company Law, which defines the term of this special form of company, established by physical persons and legal entities, who are not liable for the obligations of the company and personally cover the losses of the company up to the amount of their undertaken but unpaid deposits.

The shares of the members/partners constitute the founding capital of the LLC. Thus according to paragraph 1 of Article 68. In Article 75 of Law No. 06 / L016 on Business Organizations Official Gazette of the Republic of Kosovo / No. 9/24, a conceptual definition of this type of company is performed. The provisions of this article state: "A LLC is a legal person that is legally separate and distinct from its Shareholders. LLC is itself the holder of rights and obligations. Shares of a LLC are the units into which the ownership of the LLC is divided". It should be emphasized that the new Law on business organizations is influenced by Anglo-Saxon law that uses the term "shareholder", which refers to the affiliates of the Company Limited. Also, the stakes of the members/partners in the company are more defined as "shares". Regarding the characteristics of a LLC, only those that determine its type will be considered.

In general, the first sign of this kind of a company can be noticed by its legal status (Barbić, p.15). In this way, a LLC is a subject of law and that property, as can be seen from the Company Laws, is recognized in the three countries. Legal status includes the legal, business and procedural ability of the LLC, as an independent entity subject of law. According to the doctrinal approach, the recognition of the legal status results in the separation of the company property from the personal property of its members. This means that

\footnotetext{
${ }^{1}$ Legal framework: Law on Trade Companies ("Official Gazette of the Republic of Macedonia" no. 28/2004, 84/2005, 25/2007, 87/2008, 42/2010, 48/2010, 24/2011, 166/2012, 70 / 2013, 119/2013, 120/2013, 187/2013, 38/2014, 41/2014, 138/2014, 88/2015, 192/2015, 6/2016 30/16, 61/16, 64/18 and 120 / 18 and 290/20), Law No. 06 / L-016 On Business Organizations Official Gazette Of The Republic of Kosovo / No. 9/24 May 2018, Pristina, The Law no. 9723, dated: 03.05.2007, "On Business Registration", in Albania as amended, The Law no. 9901 dated: 14.04.2008, "On Entrepreneurs and Companies", in Albania.
} 
the company has its own property which is different from the personal property of the members/partners.

The second significant feature, present in the three Laws on trade companies, is the accepted concept in most respective legislation that this type of company belongs to the circle of capital companies. This accepted concept is reflected to the existence of the basic capital of the company that consists of the basic investments by the members. The LLC has its own body through which it operates in legal transactions. In North Macedonia, the company must contain the words "Limited Liability Company" or the abbreviation "DOO", while if it is established by one person, then is should be named as the "Limited Liability Company established by one person or "DOOEL". The Albanian name for the LLC (which is also used in Kosovo) as mentioned earlier is the abbreviation "Sh.P.K". If it is a LLC established by one person, then in its inscription it is added as "Limited Liability Company one person" or abbreviated as "SHPKNJP".

\section{Objectives of the research}

The purpose of this paper is to give a comparative-legal representation of the Company with Limited Liability, as one of the most common forms of companies in North Macedonia, Albania and Kosovo.

Through the elaboration of this paper, the legal solutions offered in the legal review in the three countries, which refer to the conceptual definition of the Limited Liability Company, the features of the company, the conditions for establishment, the issue of the share capital of the company, will be closely presented, together with the legal situation of the partner, issues related to the manner of decision-making and management of the company.

The intention of the work is to achieve the following goals:

- presenting a clear picture of the legal position of the Limited Liability Company in North Macedonia, Albania and Kosovo;

- identifying the similarities and differences regarding the legal regulation of the Limited Liability Company in the three countries;

- the advantages and disadvantages that exist in the offered legal solutions;

- The legal challenges of the legislation in the three countries regarding the harmonization of company law with EU law, given the fact that the three countries are currently facing the challenge of Euro-integration process with some differences in terms of the stages of their accession to Euro-Atlantic integration. 


\section{Methodology}

The theoretical analysis of the paper will be based on the professional literature in the relevant field of corporate law, i.e. expert analysis of experts who through their works have made a major contribution to research in the field of corporate law and which is of great importance in the preparation of this paper. On the other hand, the laws of the companies in the three countries and the legal solutions contained in them, are the legal basis on which this paper will be based. Several scientific methods will be used in the preparation of this paper: the normative method, comparative method, the inductive and deductive method, the method of abstraction and concretization, the method of classification, the method of generalization and specialization and other scientific methods.

\section{Conditions for establishing and registering of a LLC}

Although the Company Laws in the three countries under consideration generally set out the general conditions for the establishment of a LLC, the doctrinal approach makes clear the general and special conditions. In terms of special conditions, a division is made that apply to the establishment of the LLC and accordingly, they are divided into material and formal conditions (Nedkov and Grdishki-Lazarevska, 2003, p.344-354).

The material conditions for the establishment are those on which the legality in the establishment of the company depends on, and which refer to the members/partners and the company itself. The conditions that apply to the members are: the number of founders and the ability of members. Regarding the number of members/partners as founders, such provisions are contained in the three Laws on Trade Companies.

Given that a LLC is an association of one or more natural and legal persons, the possibility for a person to be a founder is envisaged. In cases where only one person appears as a founder, then it is a LLC established by one person or "DOOEL". Regarding the maximum number of members, only the Law on Trade Companies ("Official Gazette of the Republic of Macedonia" no. $28 / 2004 \ldots 290 / 20$ ), determines it through the provision contained in paragraph 2 of Article 167 of the LLC, which reads: The Limited Liability Company may have a maximum of members.

The three laws on trade companies incorporate the provisions that regulate the manner for the establishment of a LLC. Thus, Article 170 of the Law on Trade Companies ("Official Gazette of the Republic of Macedonia" no. $28 / 2004 \ldots 290 / 20$ ), regulates the way of establishment of the company in five paragraphs. Paragraph 1 of the same article reads: "a Limited Liability 
Company is established by an agreement for the company concluded by all the founders." Paragraph 2 states: "if the company is established by one person, the company agreement is replaced by a statement of the founder for the establishment of the Limited Liability Company, i.e. by a statement for the establishment of the company." The founders conclude the company agreement in person or by proxy, but the proxy must have a power of attorney certified by a public notary. The Law does not provide a power of attorney if the representative of the founder is authorized by law to conclude a contract for the company, i.e. to give a statement for the establishment of the company. Article 171 of the Law stipulates the content of the company agreement, and the statement of incorporation of the company. ${ }^{2}$

By the agreement for the company, i.e. the charter, in addition to the above mentioned issues, additional aspects can be regulated. In Albania, the provisions contained in Article 69 of the Law no. 9901 dated 14.04.2008, "On Entrepreneurs and Companies", refer to the provisions of the Joint Stock Company. According to the provisions of the JSC, the trade register contains all the data related to the registration, the charter, the acts for appointment of the management bodies of the company, as well as other acts needed for registration. ${ }^{3}$ According to the Law just referred to, in Albania, the charter is a founding act of a LLC. These provisions apply generally to all companies that should contain all the elements of the contract. Article 33 of the Kosovo

\footnotetext{
2 The company's agreement, that is the act of incorporation of the company shall contain: 1) the name and surname of founders, PIN, occupation, passport number, that is the number of the personal identification card (if the members are foreign natural persons) or other valid documents to identity his/her country and his/his citizenship and place of residence, that is the business name, the head office, PIN, if the members are legal entities; 2) the business name and head office of the company ; 3) the scope of operation of the company; 4) the duration of the company; 5) the amount of the basic capital and amount of the contribution of each member separately, if the contribution is non-monetary- detailed description and value of the contribution; 6) the manner and time period for payment of the monetary contributions that are not paid in full; 7) the name and surname, PIN of the administrator, that is the administrators (hereinafter: administrator), passport number, that is the number of the personal identification card for a foreign natural person or other document aimed at determining the identity valid in his/her country and his/his citizenship and place of residence; 8) the representation of the company; 9) the rights and liabilities of members towards the company, in addition to the payment of their contributions, as well as the rights and liabilities of the company towards the founders; 10) the manner and criteria for distribution of the profit and manner of covering the loss; 11) the management of the company, and 12) the termination of the company.

${ }^{3}$ Mandatory data for registration of the trade company in the trade register are: 1) the name; 2) the form; 3) date of establishment; 4) the identification data of the founders; 5) the seat; 6) the subject of operation; 7) data on the persons who manage the company and who represent the company in the relations with the third parties and the time of their appointment; 8) a copy of the signature of the persons representing the company in relations with third parties.
} 
Company Law stipulates the conditions for establishment and registration of a LLC. $^{4}$

\subsection{Basic capital in a LLC}

Given the fact that the LLC belongs to the circle of capital companies, the existence of the share capital of the company is logical. The positivist approach to the share capital has economic and legal significance. A second guarantee that avoids changing the nominal amount of the share capital is the designation of the share capital in Euro $(€)$ as a stable currency unit. The Law on Trade Companies ("Official Gazette of the Republic of Macedonia" no. 28/2004...290/20), in introductory part, determines the minimum amount of the basic capital of the LLC, which reads: "The basic capital cannot be less than $€ 5,000$ in Denars equivalent, according to the middle exchange rate of that currency published by the NBRM (National of the Republic of Macedonia) on the day of payment, unless the founders have agreed that it should be the day of signing the contract for the company, i.e. the statement for founding the company."

Following the conceptual and content trends that are aimed at enabling the establishment of a company with a minimum amount of share capital of one Euro, in September 2021, the Assembly of the Republic of North Macedonia adopted the Law on Amendments to the Law on Trade Companies ("Official Gazette of the Republic of Macedonia" no.215/2021 from 16.09.2021), with which the possibility of establishing a limited liability company (Simplified Limited Liability Company) was envisaged. The purpose of the amendments to the law consists in enabling the establishment of a limited liability company with a symbolic minimum amount of initial founding capital of 1 euro, by persons-citizens who have an idea for doing business, but do not have sufficient funds in the amount of at least 5,000 euros founding capital, to start their own

\footnotetext{
${ }^{4}$ To register a LLC, an Authorized Representative or Authorized Proxy must complete and submit to KBRA (Kosovo Business Registration Ageny): a form prepared by KBRA for this purpose including the following data: names and addresses of Shareholders and their Shares in the LLC, names and addresses of Managing Directors and other Authorized Representatives and Authorized proxies according to Article 24 of this Law, and information whether Managing Directors and other Authorized Representatives and Authorized proxies are authorized to represent the LLC alone or must act jointly, and if applicable, the name and address of the person competent to receive documents according to Article 25 of this Law, names and addresses of members of Board of Directors, if the LLC has a Board of Directors, a copy of the personal identification document of the Authorized Representative, Charter of the LLC, containing, the official name of the LLC, trade name of the LLC, if requested by the Authorized Representative or Authorized Proxy; number of Managing Directors of the LLC, end date, if applicable, of the LLC subject to voluntary dissolution, etc.

${ }^{5}$ Article 172 paragraph 2 of Law on Trade Companies, "Official Gazette of the Republic of Macedonia" no. 28/2004...290/20).
} 
business. With the application of the provisions of the Law, a reduction of the grey, illegal economy in the country is expected. The Law introduces a new type of limited liability company, entitled "Simplified Limited Liability Company - PDOO".

Based on this, the applicable new article stipulates that the company can have up to three founders-natural persons, one of whom is a manager, i.e a member of the management body. Given that this is a company with a shared capital of 1 euro, it is proposed to introduce a special regime for financial operations in terms of disposal of profits, as well as providing and disposing of the required reserve of the company ${ }^{6}$. (Lalicic, Boskoski, 2021).

One of the novelties is the possibility to establish a special type of company with a minimum amount of basic capital of 1 Euro. $^{7}$ The Albanian Company Law does not provide any definition of the term share capital; it only determines the minimum amount of the share capital for a LLC. In terms of determining

6 The new article stipulates that the minimum amount of the share capital of the simplified limited liability company is 1 euro, in denar counter value according to the middle exchange rate of the National Bank of the Republic of North Macedonia on the day of payment, unless the founders agreed to be the day of signing the founding act of the company. The minimum nominal amount of the business share is 10 cents in denar counter value according to the average of the National Bank of the Republic of North Macedonia on the day of payment, unless the founders agreed that it should be the day of signing the founding act of the company. The share capital and the business share in the company must be expressed in whole numbers in euros. The stakes for the taken over business shares are paid only in cash.

The application for registration of the company in the trade register is submitted after the deposits for the undertaken business shares in the company have been paid in full. The company must have a required reserve, which must include $1 / 4$ (one quarter) of the company 's profit expressed in the annual financial statements, reduced by the amount of the loss from the previous year.

The required reserve can be used for:

1) increase of the share capital by distribution of the reserve in the share capital of the company;

2) to cover the loss stated for the year for which the annual financial statements are submitted, if it is not covered by the profit realized in the previous year; and

3) to cover the loss expressed for the previous year, if it is not covered by the profit expressed in the annual financial statements for the year for which they are submitted.

The simplified type of LLC is expected to increase the number of company registrations in North Macedonia, allowing more enterprenuiers to register a company and run their business through LLC of this type.

${ }^{7}$ The introduction of this concept, as stated in the explanation of the Draft Law, derives from the Work Program of the Government of the Republic of North Macedonia (20172020), part 4. 
the amount of share capital, the Law on Trade Companies of North Macedonia is moving in the same line with some European countries which, by reducing the amount of share capital, are focused on attracting foreign capital. Thus, according to The Law no. 9901 dated: 14.04.2008, "On Entrepreneurs and Companies", in Albania, "Limited Liability Companies could not have a capital of less than 100 Leks, ${ }^{8}$ which in European currency is equal to 1 Euro. "The Kosovo legislator, in preparing the new Law on Business Organizations (LBO), in relation to the share capital in a LLC, was moving in the direction of some European legislation and did not provide any provisions about the share capital. ${ }^{8}$

\subsection{Composition and amount of the basic capital in a LLC}

The term basic investment has a double meaning. First, it denotes the goods that the members put into free permanent use of the company. Second, the part with which the members participate in the pre-agreed share capital of the company. The basic investment is presented in money or in objects and the rights that have a property value (non-monetary investment) by which the members participates in the basic capital of the company.

The Law on Trade Companies ("Official Gazette of the Republic of Macedonia" no. 28/2004...290/20), it is regulated by the act of establishment, i.e. by the agreement for the company. Each members as a founder can make only one investment, but also one investment can be jointly made by several persons. The amount of each contribution of the members cannot be less than 100 Euros in equivalent of Macedonian Denar. The contributions of the members can be monetary and non-monetary, in kind (movable and immovable property, rights). The charter of the company stipulates the method of payment of the basic deposits. In Kosovo, the Contribution of a Shareholder to a LLC in exchange for a share may be made in the form of: cash, other tangible or intangible property, labor or services already performed. Promise to provide future labor or services shall not qualify as valid contribution, and shall not be compensated in shares. The shareholder is obliged to pay to the LLC all the Contribution (s) in due time, as specified by the Charter or Agreement of the Incorporation of the LLC, or by another agreement between the shareholders. Such obligation is not excused by the owner's death, disability or other inability to pay.

\subsection{Share in the LLC}

In the literature on company law, a doctrinal conceptual definition of everything related to the share in a LLC is made. The share implies the totality of the rights

\footnotetext{
${ }^{8}$ In the previous legislation, it was determined that the smallest amount of the share capital of the LLC is 2.500 Euros, i.e. 1,000 Euros.
} 
and obligations that the members acquire a share. The term share is reserved for denoting a part of the property in the LLC. Unlike the basic investment, whose size is constant, the size of the share is variable.

The Law on Trade Companies of North Macedonia regulates the matter regarding the shares in a very explicit way. The share of the members in the company is determined according to the size of the investment made by the members, unless otherwise determined by the agreement. There is an opportunity of a disposition nature that the company agreement may determine the obligation to issue a share certificate to the members. A certificate of participation is issued as a transcript of the balance written in the book of shares. The share certificate issued to the members of the company is not a security. In Albania, the share of the members is determined by their basic investment. ${ }^{9}$ In Kosovo, the shares in the LLC are equated with the shares in the JSC. Namely, according to Article 75 paragraph 2 of the law, the shares are the units into which the ownership of the LLC is divided. A share in the LLC is the personal property of the shareholder and it may be transferred in whole or in part, subject to applicable restrictions stated in the present Law and any restrictions stated in the Charter. The charter of the LLC may, but need not, provide that the shares be evidenced by a certificate issued by the LLC.

The shares may be owned by more than one shareholder. Unless the charter of the LLC provides otherwise, all co-owners as shareholders shall exercise their voting and other rights only through a single joint representative but they are jointly and separately liable for all obligations regarding their shares.

With respect to the transfer of shares, the Law (Article 92 L-016 on Business Organizations Official Gazette Of The Republic of Kosovo/No. 9/24) notes: "Unless the charter of the LLC provides otherwise, any shareholder may transfer his/her shares, in whole or in part, by sale, pledge, gift, inheritance or other form of transfer; provided, however, that this paragraph is not interpreted or applied in any manner which aims to impair the operation of any Law regulating transactions with securities. ${ }^{10}$

\section{Comparative definition of the legal situation of members in a LLC}

The legal situation of the members in the LLC is expressed through the acquisition of a share, which had incorporated all the individual and collective

\footnotetext{
${ }^{9}$ The legal regulation of the issue of shares is regulated by Articles: 72, 73, 74 and 75 of The Law no. 9901 dated: 14.04.2008, "On Entrepreneurs and Companies", in Albania.

10. The Charter of the Limited Liability Company may impose restrictions on the transfer of Shares including but not limited to the restrictions stated in Article 93 and 94 of this Law".
} 
rights of the members. According to the doctrinal procedure the share determines its position in the company and is expressed in three directions:

a) participation of the members in the life of the company;

b) participation of the members in the distribution or profit of the company; and

c) participation of the members in the liquidation or bankruptcy estate of the Limited Liability Company (Nuredini \& Metin, 2018).

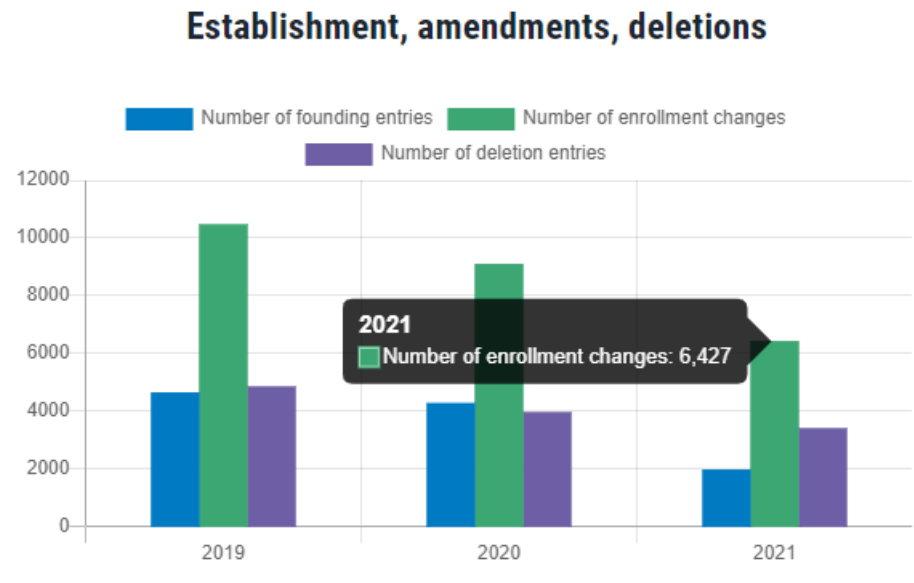

Figure 1: Number of enrollment changes as a Limited Liability Company established by a single person) or the abbreviation "DOOEL".

Source: Central Registry of the Republic of North Macedonia (2021), Statistical Bulletin 2021, available at: www.crm.com.mk, accessed: 26.05.2021.

Over the three year period, the number of business entities in the Republic of North Macedonia has shrunk considerably in all areas or categories such as in the number of entries or registered businesses, changes or modifications in activity by existing entities, and, the number of companies closed down or deleted from the register. Obviously, this was clearly due to the devastating impact of the COVID-19. 


\section{Establishment, amendments, deletions}

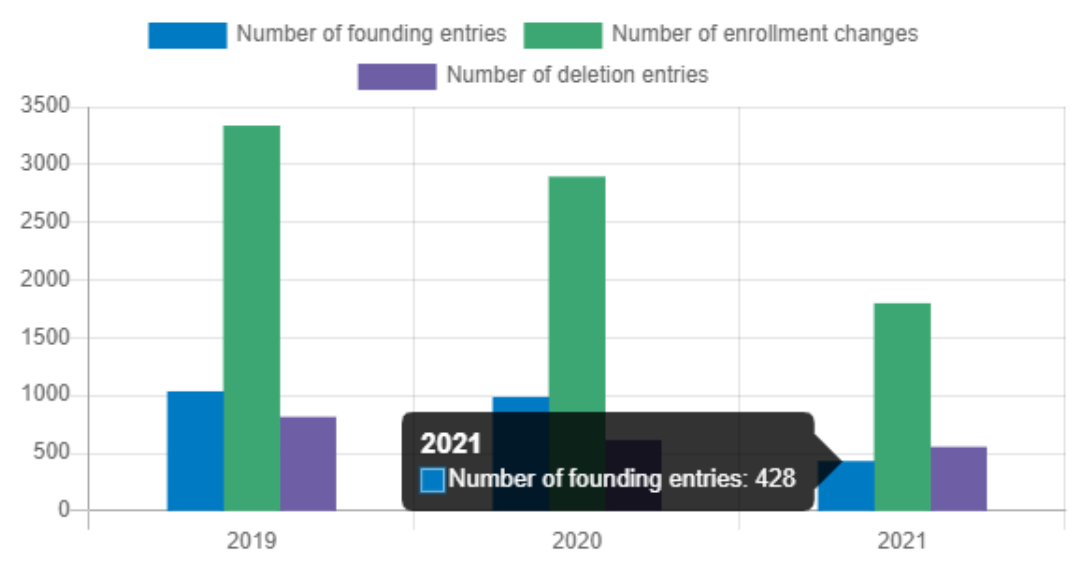

Figure 2: Number of founding entries as a LLC or the abbreviation "DOO".

Central Registry of the Republic of North Macedonia (2021), Statistical Bulletin 2021, available at: www.crm.com.mk, accessed: 26.05.2021.

As with the number of business entities in general, the number of LLCs has followed a downward trend from 2019 to mid-2021, thus less entries, enrollment changes and deletions from the registry occurred. It is an indication of a general economic recession which in particular affected the business entities as LLCs. 
X. KBRA SUMMARY FROM 2000 - MARCH 2021
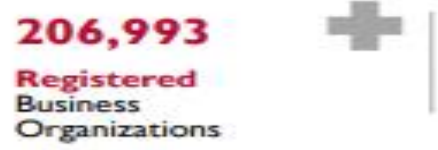

29,729

Deregistered

Business

Organizations

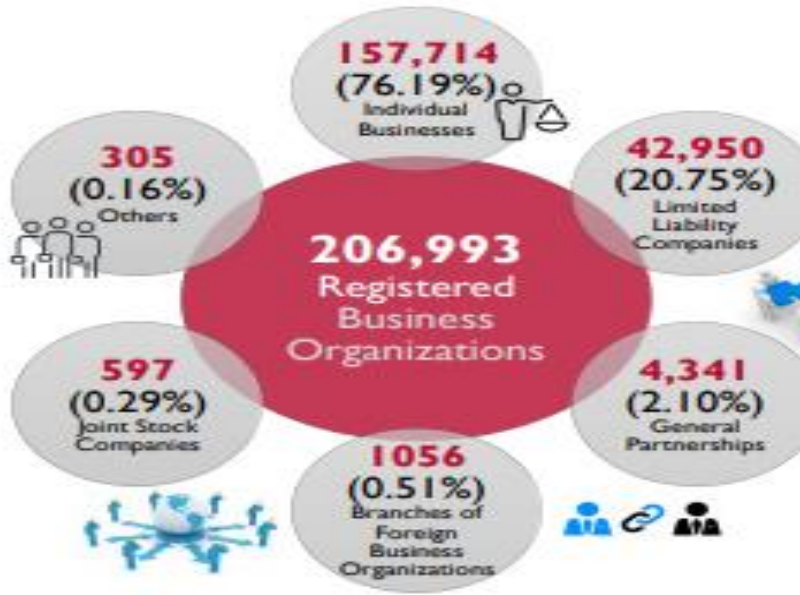

Figure 3: Basic performance indicators: Report on Business Registration in Kosovo for the period: 2000 - March 2021.

Source: Kosovo Business Registration Agency (2021), available at: www. https://arbk.rks-gov.net/page.aspx?id=2,41, accessed: 15.05.2021.

The overwhelming majority of business entities in Kosovo are registered as sole proprietors or individual business, with the LLCs accounting for more than 1/5 of the total. This structure probably might have been affected by the general economic conditions of Kosovo, which among others, has lower share of foreign companies than in the neighboring countries. The heavy dominance of sole proprietors may suggest that more complex business organizations such as partnerships, JSCs and corporations are less common as they require more skills and experience. 
Table 1: Number of founding entries as a LLC in Albania

\begin{tabular}{|l|l|}
\hline Types of companies & Active company \\
\hline Limited Liability Company & 44034 \\
\hline Joint-stock Company & 1356 \\
\hline
\end{tabular}

Source: National Business Center of Albania (2021), aviable at: https://qkb.gov.al/kerko/kerko-ne-regjistrin-tregtar/kerko-per-subjekt/, accessed: 27.05.2021.

The number of LLCs in Albania as of 2021 is almost twice as larger than in Kosovo. They also make up the largest business entities registered in Albania. Certainly, the legal aspect regulating business organization and operation has led to majority of the businesses registering as LLCs.

When comparing the legal situation of the members in the LLC, a clear distinction should be made between the position of the members, specifically the position of the members in the public company and the position of the shareholder in the Joint Stock Company as a representative company.

First, the members in a LLC do not have the capacity of trader as the members in a public company have. Second, the members in the LLC may or may not personally participate in the operation of the company, which is not the case with the members in the public company. And third, the crucial element, which distinctively distinguishes the position of the members in a LLC versus in the public company, is to reduce the risk of the company to the amount of its basic investment, as opposed to the members in the public company who entrust to the company, are accountable to them unlimitedly and in solidarity with all their property.

The Law on Trade Companies in section 5, subsection 1 regulates the issue of the rights of the members in the Limited Liability Company. More specifically, the rights of the members are explicitly noted in Article 184:

1) the right to participate in the management of the company;

2) the right to participate in the distribution of profits;

3) the right to be informed about the operation of the company;

4) the right to inspect the books and other documents of the company and

5) right to a part of the rest of the liquidation, i.e. the bankruptcy estate.

In general, in the three company laws, the duties of the members refer to:

a) the obligation to pay the deposit;

b) the duty for additional payment and

c) the duty of loyal conduct.

The Law on Trade Companies of Albania has incorporated the rights for the members in the decisions of the members in the Limited Liability Company. The payment of the basic investment is determined as a basis of 
duty. In line with the Law on Trade Companies of Albania is L-016 on Business Organizations (Official Gazette of the Republic of Kosovo/No. 9/24), which does not provide some explicit provisions that determine the bulk of rights and duties of the members in the Limited Liability Company.

It is important to note that the established relationship of the members in the LLC is not permanently related to the company itself. Analogous to the Law on Trade Companies of North Macedonia and the Law on Trade Companies of Albania in the last provisions regulate the termination of partnership in the company. The Law on Trade Companies of Albania as per provisions contained in Article 101 regulates the withdrawal of the members from the LLC. The Kosovo Law No. L-016 on Business Organizations (Official Gazette of the Republic of Kosovo/No.9/24), also regulates the issue of termination of partnership in a LLC, but the provisions governing this situation are funded as "termination of shareholder ownership."

\section{Decision making of the members and management in the LLC}

With respect to the decision-making of the members in the LLC, the question inevitably arises as to what the management will be like in this type of company given its legal nature as a "hybrid product"? As a type of small enterprise, it is normal to simplify the organization, and to create more flexibility in operation, which will not be much formalized (Barbić, p.341). The legal solution for the decision-making of the members, the Law on Trade Companies of Macedonia, in Article 213 of the same Law, cognizes two types of decision-making forms of the members: at a members meeting, and, by correspondence.

An important aspect in the doctrinal and normative analysis of a LLC is the management. In terms of structure, the LLC has the borrowed elements inherent in the capital company. As is the case with a JSC, the management of the company, understood in the broader terms, is institutionalized in the form of the bodies of the company. Namely, the management of the LLC, as well as the management of the JSC is included in the bodies of the company, the activity in the domain of the management of the company is directed through the managing bodies. The management of the company is a right of the managing bodies of the company (Nedkov, 2015).

\subsection{The shareholders' meeting}

The meeting of the members is a form of constituting the members in a management body of the company with limited liability. The shareholders' meeting is not a body of the members, but a body of the LLC. According to Article 214 of the Law on Trade Companies of North Macedonia, the meeting consists of all members, while the manager of the company who is not member can participate in the work of the meeting, without the right to vote. The 
provisions that refer to the bodies of the LLC in the Law on Trade Companies of Albania are regulated in section four of the law. Namely, Article 81 of the Companies Act contains the norms for the shareholders' meeting without specifying anything more. The rights and obligations of the shareholders' meeting are directly listed, which are defined as the responsibilities of the meeting, and for this reason they will be subject to observation, in the part by the competencies of the assembly.

The meeting of the members is convened at least once a year, in writing and within the deadlines provided by this law and the company agreement whenever the interests of the company so request. Article 82 of the Law on Trade Companies of Albania envisaged that the meeting of the members is convened whenever the interests of the company demands it. It is customary for the members to meet at least once a year. In respective Kosovo law, the shareholder assembly is the highest decision-making body of the LLC, whose general meeting shall be convened at least once (1) a year by written notice, or if specified in the charter of the LLC, by electronic mail notification. The written or electronic mail notification must contain the location, date, and hour of the general meeting and the agenda thereof, and shall be sent to all shareholders, not less than thirty (30) days before the date scheduled for the general meeting of the shareholder assembly.

\subsection{Competence of the members meeting}

The competence of the meeting has been determined, which cannot be changed unless supplemented by the company agreement. Thus, Article 215 of the Law on Trade Companies in of the Republic of North Macedonia, stipulates that the meeting of the members performs the following activities: 1) adopts the annual account and the annual financial reports, as well as the annual report on the operation of the company in the previous business year and decides on the distribution of profits to cover 2) the manager is elected and dismissed, i.e. the other managers, if the company elects several managers, and decides on concluding the contract between the company and the manager; 3) elects and dismisses the members of the supervisory board, i.e. elects and dismisses a controller, if the company has a supervisory body; 4) decides on the measures for examination and control over the management of the affairs; 5) makes a decision to initiate a procedure for compensation of the damage suffered by the company in connection with its establishment and management towards the manager, members of the supervisory board or the controller (if the company has a supervisory body) and decides on the appointment of a dispute management representative; if the company cannot represent the manager, i.e. the managers or the members of the supervisory board; 6) approves the conclusion of procurement contracts that is larger than one fifth of the share capital; 7) approves the conclusion of agreements that the company concludes with its members, manager or their relatives in the first line without restriction 
and lateral line up to the third degree, unless those agreements are concluded under the usual operating conditions of the company; 8) decides on the amendment of the contract for the company and 9) performs other activities determined by this Law. The Law no. 9901 dated: 14.04.2008, "On Entrepreneurs and Companies", in Albania, as mentioned earlier, in Article 81 determines the competencies of members in the meeting. ${ }^{11}$

According to Article 102, paragraph 2 of the L-016 On Business Organizations (Official Gazette of the Republic of Kosovo / No. 9/24), The Shareholder Assembly shall have the following competencies: Amendment of the Charter of the Limited Liability Company; reduction of or exemption from the obligation of a Shareholder to fully pay agreed contributions under Article 86 of this Law; authorization of Distributions, including purchase or repurchase of a share from a shareholder by the LLC; reduction of or exemption from the obligation of a shareholder to return distributions or other amounts which were paid to him in violation of Article 90 of this Law; issuance of new shares, transfer of shares or admission of new shareholders; a decision to dissolve the LLC or to initiate a bankruptcy procedure; a decision to merge the LLC under Part Eight of this Law, the sale, lease, pledge, mortgage or other transfer or disposition of fifty-one percent $(51 \%)$ or more of the total value of the assets of the LLC decision to elect or remove the person or persons holding the position of Managing Director; decision to elect or remove members of the Board of Directors, if the LLC has a Management Board according to the Charter of the LLC; other competencies established by law or Charter of the LLC.

\subsection{Management and supervision of the operation of the LLC}

The three Laws on Trade Companies indicate that the LLC, although it belongs to the circle of business entities, the form of management is organized in a completely different way from the management of the JSC. The manager, or the managers, are a mandatory management body of the company. Without it as the executive body, the LLC cannot be constituted and function during its further existence. In North Macedonia, when there are three or more managers in the company, then they can jointly manage the company as a management

\footnotetext{
${ }^{11}$ The shareholders' meeting is responsible for making decisions for the company for the following issues: determining the trade policies of the company; amendments to the statute (agreement); the appointment and dismissal of managers; the appointment of liquidators and certified public accountants; determining the remuneration for the managers, liquidators and certified accountants; supervising the implementation of the trade policies of the company by the managers, including the preparation of the financial statements from the operation of the company and the conduct of its activity; adopts the financial statements and the annual report of the company; reduction and increase of the share capital; reduction and withdrawal of shares; representation of the company in court and other proceedings in case of dispute with the managers; reorganization and termination of the company.
} 
body to be determined by the contract for the company. Only an individual who is legally empowered can be elected as a manager. A legal entity cannot be elected as a manager. The choice of a manager or the managers, is decided by the members. This is a general provision that should be interpreted from the aspect that there is a difference between appointing the managers in the founding phase responsibility, and the appointment of the managers in the subsequent stages of the company development. Upon establishing the company, the founders make a decision by which they appoint a manager with the contract to manage the company, or by a decision that will be made later.

In the Law no. 9901 dated: 14.04.2008, "On Entrepreneurs and Companies" in Albania, in Article 95, paragraph 1, it is stated: The shareholders' meeting appoints one or more physical persons as managers of the company. The mandate of the managers, which is determined by the charter of the company, cannot last longer than 5 years, with a possibility that the managers have the right to be re-elected. The appointment of managers produces a legal action after enrollment in the National Registration Center. The charter of the company may provide other special provisions regarding the appointment of managers. The management, which is one of the most important aspects in the functioning of LLC in the current Albanian law on companies, has followed a model similar to the German and the Anglo-Saxon (common law) model on company management, which have as the main feature the separation of partners from the responsibility of the administration, separating the figure of the administrator. While in the Italian system for LLC, two levels of management are provided, in addition to the administrator, the company also has a Board of Administration similar to the organization of JSCs. (Islamaj, 2021, p.164). The Law No. L-016 on Business Organizations (Official Gazette of the Republic of Kosovo/No. 9/24) in Article 107 notes that, a LLC shall be managed by at least one managing director.

A LLC may also establish a Board of Directors, if it is regulated in the charter of the company. If so, the authorizations, number of members, manner of appointment, term and voting method in the Board shall be provided in the charter. The provisions regarding the Board of Directors in a JSC apply respectively. Regarding the appointment of the managing directors, the shareholders of a LLC, or the Board of Directors, shall designate the specific person or persons holding the position of Managing Director. Such person (s) shall have the competencies in compliance with Article 109 of this Law. If there is more than one managing director, the shareholders or the Board of Directors shall specify different titles, duties and authorizations for each of them. The managing director may only be designed, removed or replaced by a vote of the shareholders or the Board of Directors. A managing director does not need to be a shareholder, and must be a natural person.

Every managing director is authorized to represent the LLC as an authorized representative in the conduct of its business activities, including the 
Legal regulation of limited liability company...

authorization to: conduct the ordinary business activities of the LLC and sign an agreement, or other documents necessary to exercise business activity, on behalf of the LLC if the signing of the agreement or document is reasonably related to the conduct of the ordinary business activities of the LLC.

\section{Conclusion}

The general conlucsion from the presnted analysis of the provisons of the the three conutries - Republic of North Macedonia, Albania and Kosovo is that although the three countries aspire the European Union accession, the Company Law of Republic of North Macedonia and Albania follow the narrative of Continual Law, whether the Company Law of Kosovo follows the narrative of Anglo-Saxon law.

Common feature for the Company Law of the three countries is that in all of it is accepted the following doctrinal approach - the recognition of the legal organization of this type of company through which the separation of the company property is strictly define from the personal property of its members.

Although according to doctrinal views an important feature of the Limited Liability company is that the Company has a share capital consisting of the sum of the basic deposits of the partners, still the latest legal solutions offered in the three company laws of North Macedonia, Albania and Kosovo, influenced by European trends, abandon the concept of share capital. One of the novelties is the possibility to establish a special type of company with a minimum amount of basic capital of 1 Euro. Namely, only the Laws on Trade Companies of North Macedonia and Albania provide for symbolic capital for the establishment of a limited liability company, on the other hand, the Law on Trade Companies of Kosovo does not provide for fasting of the basic capital of the company. In this part, a clear difference in the offered legal solutions should be emphasized. This year, the Assembly of the Republic of Northern Macedonia adopted the amendments to the law on trade companies which provide for the establishment of the Simplified Limited Liability Company. The applicable new article stipulates that the company can have up to three founders-natural persons, one of whom is a manager, ie a member of the management body. Given that this is a company with a share capital of 1 euro, it is proposed to introduce a special regime for financial operations in terms of disposal of profits, as well as providing and disposing of the required reserve of the company.

We consider that an important number of natural persons will take advantage of the opportunity to create Limited Liability Companies with a shared capital of 1 Euro. This finding is based on the European trends, and this is especially seen by the number of British citizens during the registration of LLC in Germany, after the reduction of the necessary founding capital. Although the basic capital remains a constitutive element of the legal solutions in the Laws on Trade Companies of Albania and North Macedonia, the question rightly arises, whether the envisaged legal solutions that can establish a company with 
limited liability and a symbolic amount of 1 Euro, move away the limited liability company as a capital type of company? I believe that the limited liability company in business practice will continue to function as a business and legal entity that has incorporated in itself the elements of personal and capital companies.

In the legislation of the three countries is noted that rights of the member are: to participate in the management of the company, to participate in the distribution of profits, to be informed about the operation of the company, to inspect the books and other documents of the company, and a part of the rest of the liquidation, i.e. the bankruptcy estate. It should be emphasized that the Macedonian Company Law uses the term "parts", while the Kosovar Company Law uses the term "shares". The term "parst" is also being used in the Albanian Company Law.

A very important aspect in the doctrinal and normative analysis of a limited liability company is the management of the company.

In terms of structure, the limited liability company basically has the borrowed elements inherent in the capital company. In a limited liability company, as is the case with a joint stock company, the management of the company, understood in the broadest sense of the word, is institutionalized in the form of the bodies of the company. Namely, the management of the limited liability company, as well as the management of the joint stock company is included in the bodies of the company, the actions in the domain of the management of the company are directed through the action of the bodies of

In the context of governance and management, the Company Law of Kosovo, in the Chapter on governance and management, stipulates that the Shareholder Assembly is the highest decision-making body of the LLC.

The used wording in the Company in Kosovo is attributed to the Anglo-saxon concept "Assembly of shareholders", and has not the same wording "General Assembly" that is used in Albanian Law. However, despite of the diferent definition used in the laws of the two different countries, the meaning is the same - the highest decision-making body of the LLC.

The management of a limited liability company is organized in a very different way compared to that of a joint stock company. Namely, according to the Company Law of Republic of North Macedonia, LLC is managed by a manager, ie managers.

The way of management, which is one of the most important aspects in the functioning of LLC in the current Albanian Company Law, has followed a model similar to the German model and the Anglo-Saxon (common law) model of company management, which have as the main feature the separation of partners from the responsibility of the management, separating the figure of the manager. 
On the other hand, in terms of management, the Company Law of Kosovo stipulates that a LLC shall be managed by at least one Managing Director. A LLC may also establish a Board of Directors, if it is regulated in the Charter of the Limited Liability Company. If the Limited Liability Company establishes a Board of Directors, its authorizations, number of members, manner of appointment, term and voting method in the Board shall be provided in the Charter of the LLC. The provisions regarding the Board of Directors of Joint Stock Company apply respectively.

Finally, it should be emphasized that the manager/s is a mandatory function (body) of the company. A limited liability company cannot be established without it, nor can the normal functioning and conduct of business activity be imagined.

At the end, we can conclude that the Company Law of the three countries in one way or another are almost fully harmonized with the European legislation in the field of Company law, with some small differences that do not make any notable difference.

\section{References}

Barbić, J. (2020). Pravo Društava (Company Law), Knjiga druga, Društva Kapitala, Sedmo izmijenjeno i dopunjeno izdanje, Organizator, Zagreb.

Central Registry of the Republic of North Macedonia (2021). Statistical Bulletin 2021, available at: www.crm.com.mk, Accessed: 26.05.2021.

Dine, J., Blacher, M. (2016). Ligji për tregtarët dhe shoqëritë tregtare: Teksti me shpjegime (The Law on Trading Companies: Content and Interpretation), revised version, Deutsche Gesellschaft für Internationale Zusammenarbeit (GIZ) GmbH, Gent Grafik, Tirana.

Dine J., Bletcher M. (2016). Law on Traders and Companies, Explanatory Text, Revised Version", GIZ edition.

Islamaj, F. (2021). Shoqëria me përgjegjësi të kufizuar në Shqipëri (Limited Liability Company in Albania), PhD Dissertation, Faculty of Law, University of Tirana, Tirana.

Lalicic, Boskoski (2021, September). Simplified Limited Liability CompanyNorth Macedonia https://lblaw.com.mk/en/simplified-limitedliability-company-north-macedonia/, Accessed on 10.10.2021.

Koevski, G., Tushevska, S. (2020). Analysis of the possibility for introduction of a Limited Liability Company with one Euro minimum paid-in capital based on the German model, Faculty of Law, Goce Delcev UniversityStip, $\quad$ Retrieved from https://js.ugd.edu.mk/index.php/YFL/article/view/4103, Accessed on 21.05.2021.

Kosovo Business Registration Agency (2021). available at: www. https://arbk.rks-gov.net/page.aspx?id=2,41, Accessed: 15.05.2021. 
Mock, S. (2021). The Mini-GmbH Unternehmergesellschaft haftungsbeschränkt (UG) in Germany:, Modelli di Impresa Societaria fra Tradizione e Innovazione nel Contesto Europeo, Retrieved from https //papers.ssrn.com/sol3/papers.cfm?abstract_ id $=2887563$, Accessed on 18.05.2021).

National Business Center of Albania (2021), aviable at: https://qkb.gov.al/kerko/kerko-ne-regjistrin-tregtar/kerko-persubjekt/, Accessed on 27.05.2021.

Недков, Б. \& Грдишки-Лазаревска (2003). Право на друштвата (Company Law), Книга прва, Сигмапрес, Скопје.

Недков, М. (2015). Управување со Друштвото со ограничена одговосрност (Management of the Limited Liability Company), available at: http://mla.org.mk/wpcontent/uploads/2015/01/2.\%D0\%92\%D0\%BE\%D0\%B4\%D0\%B8\% D1\%87-

\%D0\%A3\%D0\%BF\%D1\%80\%D0\%B0\%D0\%B2\%D1\%83\%D0\%B2 $\% \mathrm{D} 0 \% \mathrm{~B} 0 \% \mathrm{D} 1 \% 9 \mathrm{~A} \% \mathrm{D} 0 \% \mathrm{~B} 5-\% \mathrm{D} 1 \% 81 \% \mathrm{D} 0 \% \mathrm{BE}-$

$\%$ D0\%94\%D0\%9E\%D0\%9E1.pdf, Accessed on 10.12.2021.

Nuredini, B. \& Metin, H. (2018). Comparative definition of the co-founder's legal status in Limited Liability Companiesin Albania, Macedonia and Kosovo, UBT International Conference. 284. Retrieved from https://knowledgecenter.ubt-uni.net/conference/2018/all-events/284, Accessed on 24.05.2021.

\section{Legal acts}

Law no. 06 / L-016 On Business Organizations. Official Gazette of the Republic of Kosovo/ No. 9/24 May 2018, Pristina.

Law on Trade Companies ("Official Gazette of the Republic of Macedonia" no. 28/2004, 84/2005, 25/2007, 87/2008, 42/2010, 48/2010, 24/2011, 166/2012, 70 / 2013, 119/2013, 120/2013, 187/2013, 38/2014, 41/2014, 138/2014, 88/2015, 192/2015, 6/2016 30/16, 61/16, 64/18 and $120 / 18$ and 290/20).

Law on Amendments to the Law on Trade Companies ("Official Gazette of the Republic of Macedonia” no.215/2021 from 16.09.2021)

Law no. 9723, dated: 03.05.2007, "On Business Registration", in Albania as amended.

Law no. 9901 dated: 14.04.2008, "On Entrepreneurs and Companies", in Albania.

Law on the Central Register of the Republic of North Macedonia ("Official Gazette of the Republic of Macedonia" No. 50/2001, 49/2003, 109/2005).

Law on one-stop shop system and keeping the trade register and the register of other legal entities ("Official Gazette of the Republic of Macedonia" No. 84/2005, 13/2007, Decision of the Constitutional Court 12.09.2007, 150/2007). 